\title{
Ovicidal activity of succinic acid isolated from sisal waste (Agave sisalana) against gastrointestinal nematodes of goats
}

\author{
Nathália Silva de Souza Santos ${ }^{1}$ Jener David Gonçalves Santos ${ }^{2}$ Francianne Oliveira Santos ${ }^{1}$ \\ Taiane Menezes Serra ${ }^{1}$ Hélimar Gonçalves de Lima ${ }^{1}$ Mariana Borges Botura ${ }^{2}$ \\ Alexsandro Branco ${ }^{2}$ Maria José Moreira Batatinha ${ }^{*}$
}

'Escola de Medicina Veterinária, Universidade Federal da Bahia (UFBA), 40170-110, Salvador, BA, Brasil. E-mail: mjmb@ufba.br. "Corresponding author.

${ }^{2}$ Universidade Estadual de Feira de Santana (UEFS), Feira de Santana, BA, Brasil.

ABSTRACT: This study was conducted to evaluate the in vitro anthelmintic activity of the succinic acid (SA) isolated from sisal waste against gastrointestinal nematodes of goats, using the egg hatching and larvae motility assays. In addition, potential cytotoxicity of SA on Vero cell cultures was investigated by means of MTT (3-4,5-dimethylthiazol-2-yl, 2,5diphenyltetrazolium bromide) test. The SA induced a significant inhibition of egg hatching $(P<0.05)$ at all concentrations tested $\left(60\right.$ to $\left.250 \mu g \mathrm{~mL}^{-1}\right)$, and the concentrations to inhibit $50 \%\left(E C_{50}\right)$ and $90 \%$ $\left(E C_{90}\right)$ values (mean \pm standard deviation) were $90.3 \pm 2.8$ and $130.6 \pm 3.5 \mu \mathrm{g} \mathrm{L}^{-1}$, respectively. The SA has not shown larvicidal activity. The $S A$ was less toxic to the Vero cells, with the mean percentage of cell viability equal to $85 \pm 6.2 \%$ at the concentration of $130 \mu g L^{-1}$. The results suggested that $S A$ has potential anthelmintic effect; although, more research is needed to confirm its activity in vivo.

Key words: Agave sisalana, sisal waste, succinic acid, anthelmintic, goats.

Atividade ovicida do ácido succínico isolado do resíduo de sisal

(Agave sisalana) sobre nematoides gastrintestinais de caprinos

RESUMO: O objetivo deste estudo foi avaliar a atividade anti-helmíntica in vitro do ácido succínico (AS) isolado do resíduo de sisal sobre nematódeos gastrointestinais de caprinos, utilizando os ensaios de inibição da eclosão de ovos e motilidade larval. Além disso, a citotoxicidade do AS em culturas de células Vero foi investigada empregando-se o teste de MTT (brometo de 3-4,5-dimetiltiazol-2-ilo, brometo de 2,5-difeniltetrazólio). O AS promoveu redução significativa no percentual de eclosão de ovos $(P<0,05)$ em todas as concentrações testadas

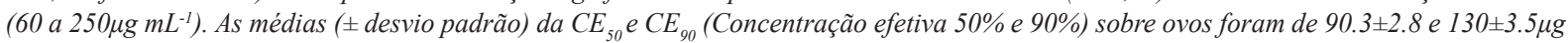
$m L^{-1}$, respectivamente. OAS não apresentou atividade larvicida. O AS foi menos tóxico para as células Vero, com média do percentual de viabilidade celular igual a $85 \pm 6.2 \%$ na concentração de $130 \mu \mathrm{g} \mathrm{mL}^{-1}$. Os resultados sugerem que o AS tem potencial efeito anti-helmíntico, embora sejam necessários a realização de estudos in vivo para confirmar seu uso terapêutico.

Palavras-chave: Agave sisalana, residuos de sisal, ácido succínico, anti-helmíntico, caprinos.

\section{INTRODUCTION}

Parasitic infections caused by gastrointestinal nematodes in goats remain as a global challenge (JABBAR et al., 2006; NABUKENYA et al., 2014). These infections are responsible for a significant economic impact due to weight loss, reduced milk production and delayed growth (ROEBER et al., 2013). Development of nematode resistance to drugs commercially available encouraged the search for products of plant origin (FERREIRA et al., 2013). Such products can provide potential alternatives to the use of synthetic nematicides because they degrade to non-toxic products and cause fewer side effects to non-target organisms and within the broader environment.
Succinic acid (SA) is a product of the metabolism of plants and micro-organisms (WANG et al., 2011) and has shown biological activities, such as anxiolytic (CHEN, 2003; VOLCHEGORSKII et al., 2015), and the induction for IL-8 production in inflammatory processes (GRAHAM et. al., 2013). CHUNGSAMARNYART \& JANSAWAN (2001) reported the action of SA, isolated from the fruit of Tamarindus indicus (tamarind), on engorged females of Rhipicephalus (Boophilus) microplus. In this sense, previous studies of short-chain organic acids revealed nematicide action (SANTOS et al., 2007; NGUYEN et al., 2013).

Agave sisalana (sisal) is of a great economic interest because it is a source of fiber in semi-arid areas. Brazil is the largest producer and 
exporter of sisal fibers worldwide (IBGE, 2013), where $4 \%$ of the sisal leaves produce fiber and the remaining material (waste) is discarded (SHARMA and VARSHNEY, 2012). Our research group has investigated the biological activity of different extracts and fractions obtained from sisal waste against nematodes of goats. In the context, the flavonoid and saponin fractions from ethyl acetate extract showed ovicidal and larvicidal effects, respectively (SILVEIRA et al., 2012; BOTURA et. al., 2013; SANTOS et al., 2015). In a continuous study, we described the evaluation of the in vitro anthelmintic and cytotoxicity activity of the SA isolated from the same extract on eggs and larval stage (L3) of nematodes of goats, and on African green monkey's kidney cell line (Vero).

\section{MATERIALS AND METHODS}

\section{Materials}

Ethyl acetate, ethanol and methanol (analytical grade) from VETEC were used. Analytical thin-layer chromatography (TLC) was performed on commercial aluminum plates coated with silica gel (0.025mm) (Merck, Darmstadt, Germany). Spots were visualized by spraying with $1 \mathrm{M} \mathrm{H}_{2} \mathrm{SO}_{4}$ and heating to $100^{\circ} \mathrm{C}$. Silica gel (Kielselgel $60,70-230$ mesh) was used for open-column chromatography. Carbon-13 Nuclear Magnetic Resonance $\left({ }^{13} \mathrm{C}\right.$ NMR) spectra were obtained using a Varian Gemini 300 equipment.

\section{Plant material}

The Agave sisalana waste was collected after the process of decortication of the leaves, on a sisal farm located in Valente, in the state of Bahia (S $\left.11^{\circ} 24^{\prime} 53.4^{\prime \prime}\right)$, in May 2012.

\section{Obtaining of succinic acid}

The obtaining of succinic acid from sisal waste was performed using the methodology described by SANTOS et al. (2015). Briefly, the ethyl acetate extract was subjected to open-column chromatography packed with silica gel to yield the succinic acid in fractions eluted with EtOAc (100\%) and EtOAc/MeOH (8:2). Crystals obtained were identified with ${ }^{1} \mathrm{H}$ NMR (Proton Nuclear Magnetic Resonance) and ${ }^{13} \mathrm{C}$ NMR (Carbon Nuclear Magnetic Resonance).

\section{Anthelmintic activity}

All early-life stages of trichostrongylids used in this study were obtained from goats naturally infected and kept at the School of Veterinary Medicine, Federal University of Bahia. The generic identification of the nematode population was determined according to UENO and GONÇALVES (1998). The feces cultures of those animals indicated the presence of $86 \%$ of Haemonchus spp., 10\% Oesophagostomum spp. and 4\% Trichostrongylus spp.

\section{Egg hatching assay (EHA)}

Eggs were isolated from feces of goats naturally infected with gastrointestinal nematodes as described by HUBERT and KERBOEUF (1992). The bioassay was performed following COLES et al. (1992). Egg suspension was distributed in 96-well plates (100 fresh eggs $100 \mu \mathrm{L}^{-1} /$ well) and mixed with the same volume of the SA dissolved in distilled water at different concentrations $(60 ; 90 ; 130 ; 180$ and $\left.250 \mu \mathrm{g} \mathrm{mL}^{-1}\right)$. Negative and positive controls were distilled water and thiabendazole $(25 \mu \mathrm{g}$ $\left.\mathrm{mL}^{-1}\right)$, respectively. After a 48-hour incubation at $25^{\circ} \mathrm{C}$, egg hatching was blocked by the addition of Lugol's iodine solution. Number of eggs and larvae L1 per well was counted. Inhibition percentage of egg hatching was determined using the following ratio: [Number of eggs/(number of eggs + number of L1 larvae)] x 100.

\section{Larval motility assay}

For the larval motility assay, a suspension of infective larvae $\left(\mathrm{L}_{3}\right)$ was distributed in 24-well plates (50 larvae/100 $\mu \mathrm{L} /$ well) and added with the succinic acid $\left(1,000 \mu \mathrm{g} \mathrm{mL} \mathrm{m}^{-1}\right)$ in the same volume $(100 \mu \mathrm{L})$ (FERREIRA et al., 2013). Both a negative control with distilled water and a positive control with levamisole $\left(250 \mu \mathrm{g} \mathrm{mL}^{-1}\right)$ were also prepared. The results were expressed as the percentage of mobile larvae.

\section{Cytotoxicity assay}

The commercial Vero cell line (Vero ATCC $^{\circledR}$ CCL-81 ${ }^{\mathrm{TM}}$ ) was obtained from African Green Monkey's (Cercopithecus aethiops) kidney and maintained in RPMI (Roswell Park Memorial Institute) medium supplemented with penicillin $\mathrm{G}$ (100UI $\left.\mathrm{mL}^{-1}\right)$, streptomycin $(100 \mathrm{mg} / \mathrm{mL})$ and $10 \%$ fetal equine serum. Cells were cultured at $37^{\circ} \mathrm{C}$ in a humidified $5 \%$ $\mathrm{CO}_{2}$ incubator.

In the moment of the experiments, cells were placed in 96-well plates at a density of $3.5 \times 10^{4}$ cells $\mathrm{mL}^{-1}$ and were cultured for $24 \mathrm{~h}$ 
prior to treatment. Thereafter, cells were treated with succinic acid diluted in RPMI medium (60; 90; $130 ; 180$ and $\left.250 \mu \mathrm{g} \mathrm{mL}^{-1}\right)$. Negative control group was treated only with RPMI. Plates were kept in an incubator for an additional $24 \mathrm{~h}$ and then the assessment of cell viability was performed by means of the 3-(4,5-dimethylthiazol-2-yl)-2,5diphenyltetrazolium bromide (MTT) test according to HANSEN et al. (1989).

After the treatment period, the culture medium was removed and MTT (1mg $\left.\mathrm{mL}^{-1}, 100 \mu \mathrm{L}\right)$ was equally added to each well. After three hours of incubation, lysis buffer containing $20 \%$ sodium dodecyl sulfate (SDS) and $50 \%$ dimethylformamide (DMF) was added, maintaining the plates incubated for another $12 \mathrm{~h}$. Optical absorbance was measured using a wavelength (405-600nm) plate reader. Results were expressed as percentages of viability of treated groups related to the control group.

\section{Statistical analysis}

Results are expressed as mean \pm standard deviation (S.D.). The data were analyzed using an ANOVA and were compared using Tukey's test (5\%). For each biological assay, three independent experiments were performed, with five repetitions for each concentration and controls. The $\mathrm{EC}_{50}$ and $\mathrm{EC}_{90}$ for the ovicidal tests were individually calculated for each experiment using a non-linear regression analysis All statistical analyses were performed with the GraphPrism version 5.0.

\section{RESULTS AND DISCUSSION}

The succinic acid (SA) was isolated from the ethyl acetate extract from sisal waste in accordance with SANTOS et al. (2015) and its chemical characterization was made using NMR data. The ${ }^{13} \mathrm{C}$ NMR (Figure 1) showed only three signals attributed to the two methylenic carbons and two carbons of the carboxylic acid.

The SA inhibited egg hatching in a concentration-dependent manner. The mean percentage inhibition of egg hatching ranged from 15.2 to $97.2 \%$ (Figure 2). The mean and standard deviations of $\mathrm{EC}_{50}$ and $\mathrm{EC}_{90}$ of the three experiments were $90.3 \pm 2.8$ and $130.6 \pm 3.5 \mu \mathrm{g} \mathrm{mL}^{-1}$, respectively. In the larval motility assay, the mean percentage of mobile larvae observed in the group treated with SA $(82 \pm 7.7 \%)$ did not differ statistically $(\mathrm{P}>0.05)$ from the negative control $(98.2 \pm 1.5 \%)$.

The SA was effective in preventing the development of the eggs. According to VERCRUYSSE et al. (2001), a synthetic product is effective when it promotes anthelmintic activity above $90 \%$. The mean value reported for the $\mathrm{EC}_{90}$ (130.6 $\mu \mathrm{g} \mathrm{mL}^{-1}$ ) was, respectively, equal and higher to those reported by BOTURA et al. (2013) for the ethyl acetate extract $\left(130 \mu \mathrm{g} \mathrm{mL}^{-1}\right)$ and for flavonoid fraction $\left(70 \mu \mathrm{g} \mathrm{mL}^{-1}\right)$ obtained in this same sisal residue extract. The authors attribute this ovicidal activity to the presence of homoisoflavonoids detected in the chemical analysis of flavonoid fraction (BOTURA et al., 2013). Bearing in mind that the succinic acid used in this study was also obtained from the ethyl acetate

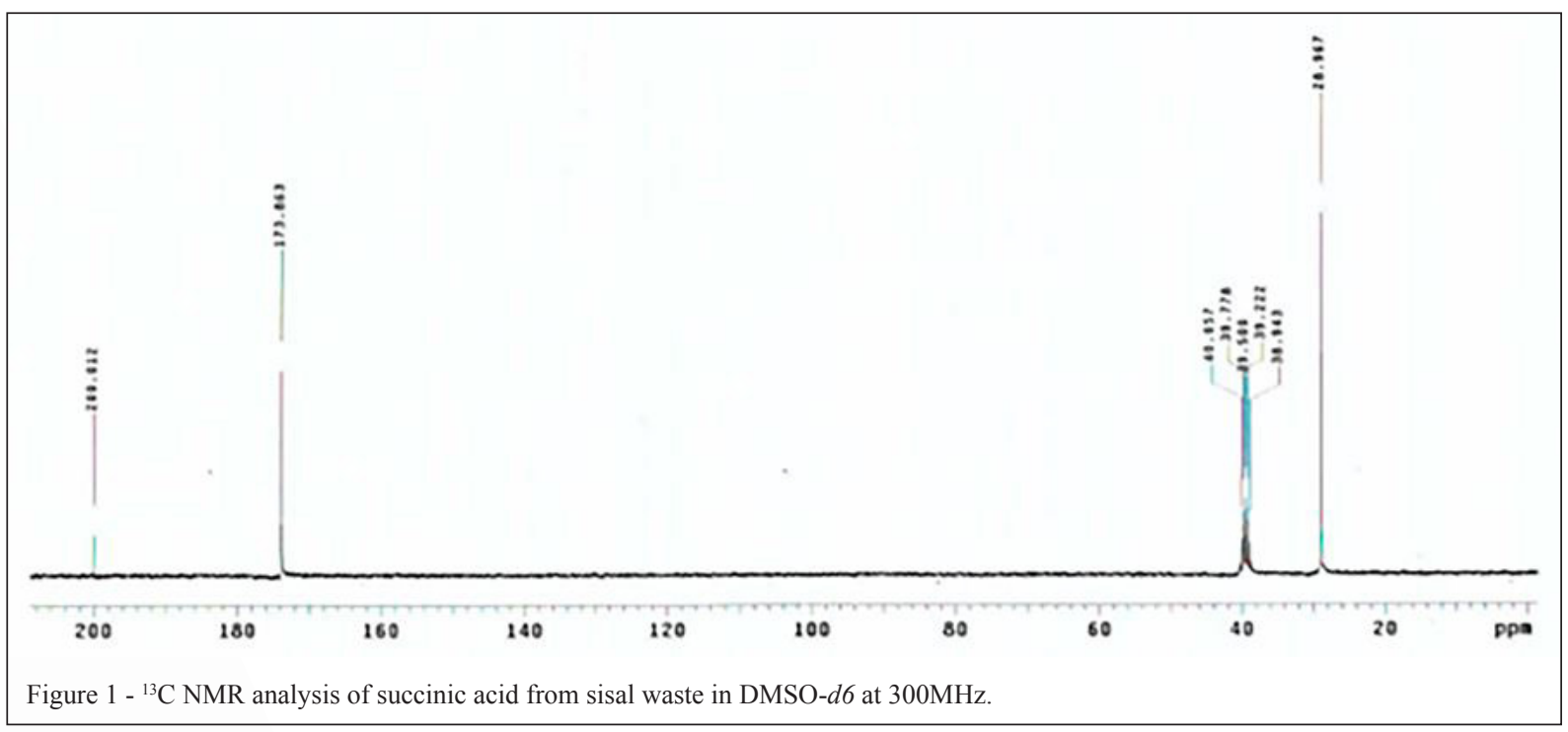

Ciência Rural, v.47, n.8, 2017. 


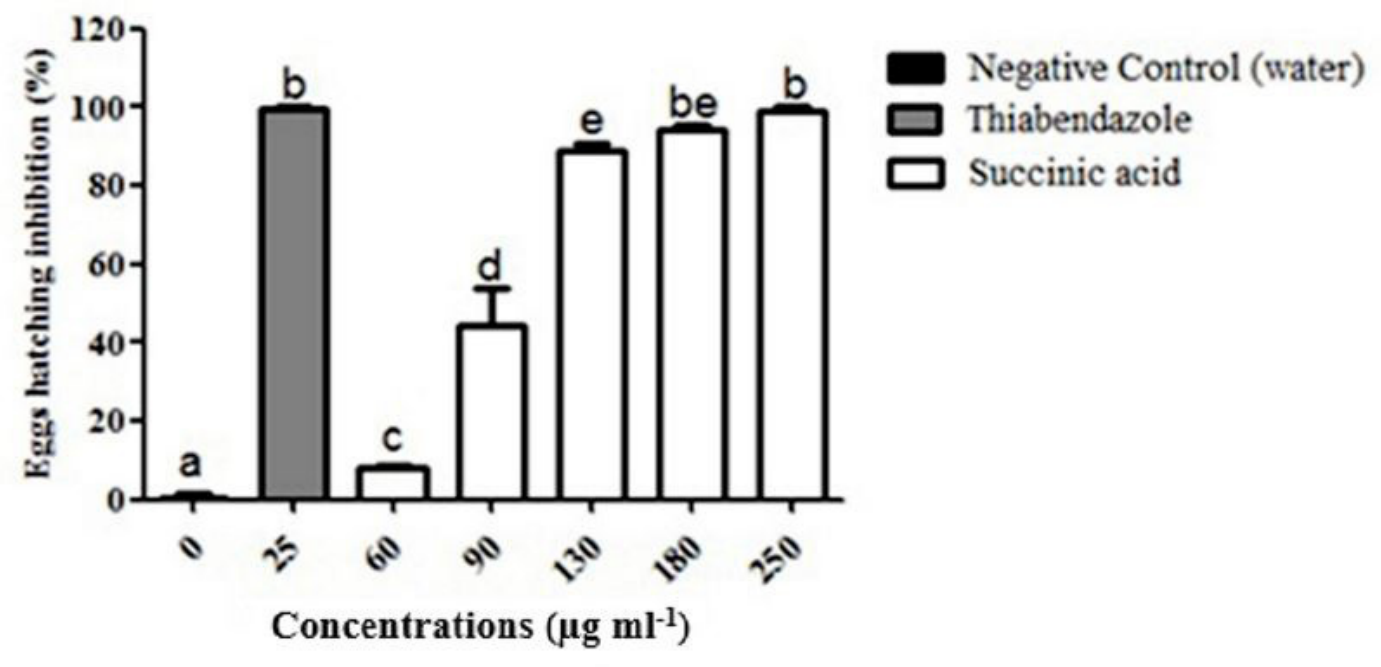

Figure 2 - Inhibition percentage (mean \pm S.D) of egg hatching of gastrointestinal nematode eggs of goats treated with succinic acid (SA) and thiabendazole.

extract from the sisal liquid residue, the results suggested a possible synergistic or additive action of the SA with these flavonoids.

Ovicidal activities of isolated organic acids from plants have been reported. Research results performed by SANTOS et al. (2007) have demonstrated the action of oleanolic acid obtained from the Rheedia gardneriana fruit on the egg hatching of Meloidogyne incognita, yet with low percentage of hatching inhibition $(63.5 \%)$ after ten days of treatment using the concentration of $800 \mu \mathrm{g}$ $\mathrm{mL}^{-1}$, which was six times greater than the mean of $\mathrm{EC}_{90}\left(130.6 \mu \mathrm{g} \mathrm{mL}^{-1}\right)$ reported in this study.

The succinic acid had no effect on larval motility at the concentration used. BOTURA et al. (2013) reported moderate larvicidal activity of the saponin fraction from the sisal waste (efficacy of $64.1 \%)$. These results suggested the participation of one more chemical component in the anthelmintic activity of $A$. sisalana.

The cytotoxicity effects of SA on Vero cells were reported in figure 3 . The treatment with SA ( 90 to $250 \mu \mathrm{g} \mathrm{mL}^{-1}$ ) induced a significant reduction in the percentage of cell viability compared to the negative control $(\mathrm{P}<0.05)$, with mean of percentage from $90 \pm 5.13$ to $78.4 \pm 5.1 \%$, respectively. According to the ISO 10993-5 (2009), a substance is considered toxic (MTT test) when it showed percentages of over $30 \%$ of non-viable cells. Thus, no sign of cytotoxicity was observed after the exposition with SA. This result suggested low potential for toxicity of succinic acid at a concentration in which it has pronounced anthelmintic effect.

\section{CONCLUSION}

The succinic acid from sisal waste (Agave sisalana) showed an ovicidal activity against gastrointestinal nematodes of goats and low potential for toxicity on Vero cell cultures, suggesting the participation and promising potential of this constituent on the anthelmintic activity reported for Agave sisalana; although, it did not show effectiveness on the larvae of these parasites. Further research, including in vivo studies, are required in order to assess the antiparasitic potential of this acid. 


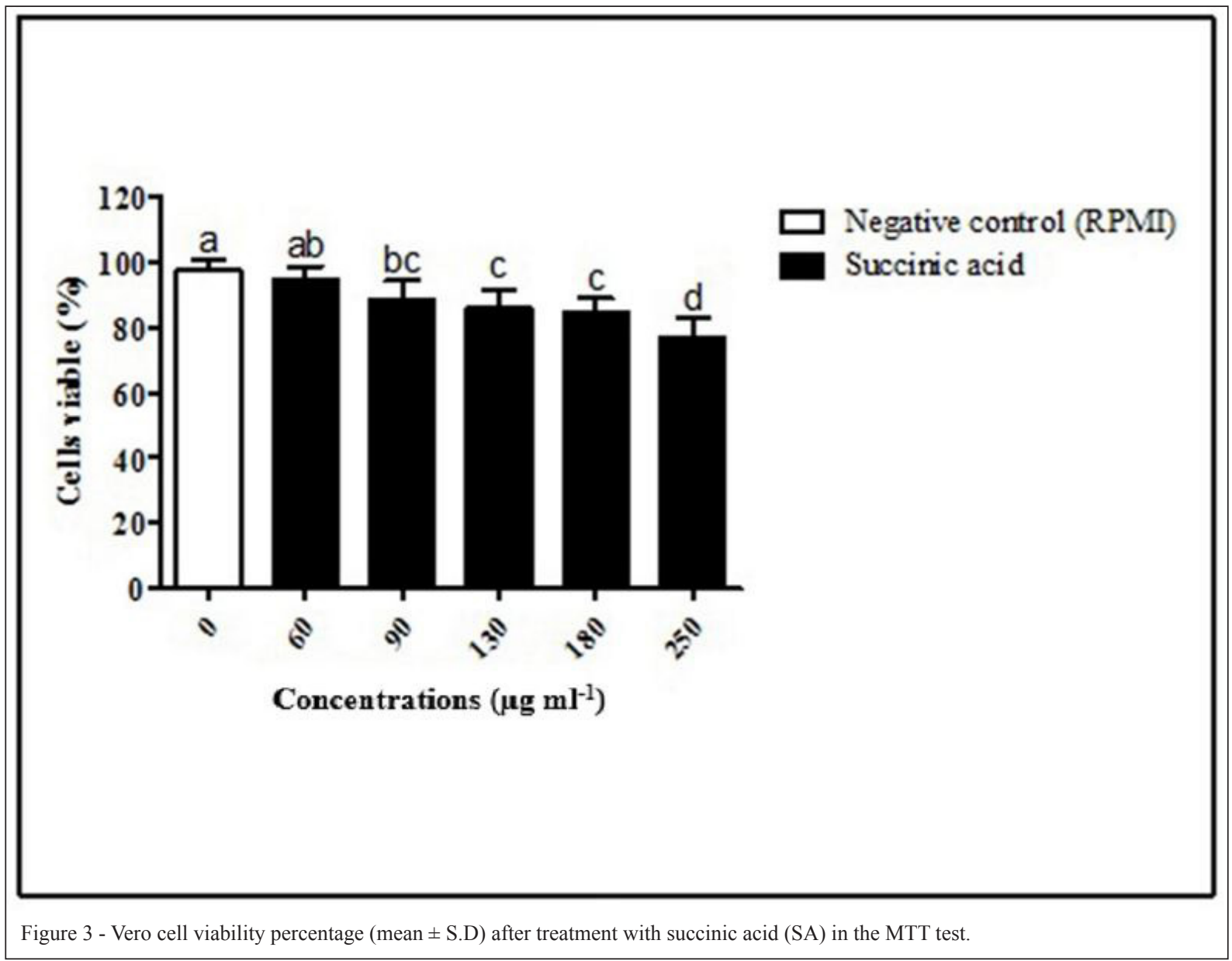

\section{ACKNOWLEDGMENTS}

We would like to thank the Conselho Nacional de Desenvolvimento Científico e Tecnológico (CNPq), Universidade Estadual de Feira de Santana (UEFS) and Universidade Federal da Bahia (UFBA) for the financial support. We also thank teacher Abilio Borghi for the grammar review of the manuscript.

\section{BIOETHICS AND BIOSSECURITY COMMITTEE APPROVAL}

We, authors of the article entitled "Ovicidal activity of succinic acid isolated from sisal waste (Agave sisalana) against gastrointestinal nematodes of goats" declare, for all due purposes, that the project that gave rise to the present data $t$ has not been submitted for evaluation to the Ethics Committee of the Universidade Federal da Bahia / Escola de Medicina Veterinária e Zootecnia, but we are aware of the content of the Brazilian resolutions of the Conselho Nacional de Controle de Experimentação Animal (CONCEA) <http://www.mct.gov.br/index.php/content/ view/310553.html $>$ if it involves animals. Thus, the authors assume full responsibility for the data presented and are available for possible questions, should they be required by the competent authorities.

\section{REFERENCES}

BOTURA, M.B. et al. In vitro ovicidal and larvicidal activity of Agave sisalana Perr. (sisal) on gastrointestinal nematodes of goats. Veterinary Parasitology, v.192, p.211-217, 2013. Available from: $<$ http://www.sciencedirect.com/science/article/pii/ S0304401712005596>. Accessed: Mar. 10, 2014. doi: 10.1016/j. vetpar.2012.10.012

CHEN, S.W. Anxiolytic-like effect of succinic acid in mice. Life Sciences, v.73, p.3257-3264, 2003. Available from: $<$ http://www. sciencedirect.com/science/article/pii/S0024320503008105>. Accessed: Mar. 10, 2014. doi: 10.1016/j.1fs.2003.06.017.

CHUNGSAMARNYART, N.; JANSAWAN, W. Effect of Tamarindus indicus L. against the Boophilus microplus. Kasetsart Journal (Natural Science), v.35, p.34-39, 2001. Available from: $<$ http://kasetsartjournal.ku.ac.th/abstractShow.aspx?param $=$ YXJ0 aWNsZUlEPTEwOT18bWVkaWFJRD05MjU=>. Accessed: Apr. 28,2014

COLES, G.C. et al. World association for the advancement of veterinary parasitology (WAAVP) methods for the detection of anthelmintic resistance in nematodes of veterinary importance. Veterinary Parasitology, v.44, p.35-44, 1992 Available from: <http://www.sciencedirect.com/science/ 
article/pii/030440179290141U>. Accessed: Apr. 12, 2014. doi: 10.1016/0304-4017(92)90-141-U

FERREIRA, L.E. et al. In vitro anthelmintic activity of aqueous leaf extract of Annona muricata L. (Annonaceae) against Haemonchus contortus from sheep. Experimental Parasitology, v.134, p.327332, 2013. Available from: <http://www.sciencedirect.com/ science/article/pii/S0014489413001094>. Accessed: June 23, 2014. doi: 10.1016/j.exppara.2013.03.032

GRAHAM, L.S. et al. Effects of succinic acid and other microbial fermentationproductsonHIVexpressioninmacrophages. BioResearch Open Access, v.2, p.385-391, 2013. Available from: $<$ http://online. liebertpub.com/doi/pdfplus/10.1089/biores.2013.0013>. Accessed: Oct. 27, 2014. doi: 10.1089/biores.2013.0013.

HANSEN, M.B. et al. Re-examination, and further development of a precise and rapid dye method for measuring cell growth/ cell kill. Journal Immunological Methods, v.119, p.203-210, 1989. Available from: <http://www.sciencedirect.com/science/ article/pii/0022175989903979>. Accessed: Aug. 13, 2014. doi: 10.1016/0022-1759(89)90397-9.

HUBERT, J.; KERBOEUF, D. A micro larval development assay for the detection of anthelmintic resistance in sheep nematodes. Veterinary Record, v.130, p.442-446, 1992. Available from $<$ http://veterinaryrecord.bmj.com/content/130/20/442.abstract $>$. Accessed: Oct. 23, 2014. doi: 10.1136/vr.130.20.442.

INSTITUTO BRASILEIRO DE GEOGRAFIA E ESTATÍSTICA. Produção da pecuária municipal. 2013. Online. Available from: <http://www.ibge.gov.br/<3ftp://ftp.ibge.gov.br/Producao Pecuaria/Producao da Pecuaria Municipal/2013/ppm2013.pdf $>$. Accessed: June 08, 2015 .

INTERNATIONAL STANDARD, ISO 10993-5. Biological evaluation of medical devices - part 5: Tests for in vitro cytotoxicity. Berlin, Germany, 2009.

JABBAR, A. et al. Anthelmintic resistance: the state of play revisited. Life Sciences, v.79, p.2413-2431, 2006. Available from: <http://www.sciencedirect.com/science/article/pii/ S0024320506006436>. Accessed: June 01, 2015. doi: 10.1016/j. lfs.2006.08.010.

NABUKENYA, I. et al. Anthelmintic resistance in gastrointestinal nematodes in goats and evaluation of FAMACHA diagnostic marker in Uganda. Veterinary Parasitology, v.205, p.666-675, 2014. Available from: <http://www.sciencedirect.com/science/ article/pii/S0304401714004063>. Accessed: Nov. 24, 2014. doi: 10.1016/j.vetpar.2014.07.019.

NGUYEN, D.M.C. et al. Nematicidal activity of 3,4-dihydroxybenzoic acid purified from Terminalia nigrovenulosa bark against Meloidogyne incognita. Microbial Pathogenesis, v.59-60, p.52-59, 2013. Available from: $<\mathrm{http}: / / \mathrm{www}$.sciencedirect. com/science/article/pii/S088240101300051X>. Accessed: Apr. 30, 2015. doi: 10.1016/j.micpath.2013.04.005.
ROEBER, F. et al. Impact of gastrointestinal parasitic nematodes of sheep, and the role of advanced molecular tools for exploring epidemiology and drug resistance - an Australian perspective. Parasites \& Vectors, v.6, p.1-13, 2013. Available from: <http://parasitesandvectors.biomedcentral.com/ articles/10.1186/1756-3305-6-153>. Accessed: Apr. 2015. doi: $10.1186 / 1756-3305-6-153$

SANTOS, M.H. et al. Efeito de constituintes químicos isolados da casca do fruto de Rheedia gardneriana sobre a eclosão de juvenis de Meloidogyne incognita Raça 3. Latin American Journal Pharmacy, v.26, p.711-714, 2007. Available from: <http:// www.latamjpharm.org/resumenes/26/5/LAJOP_26_5_1_10.pdf $>$. Accessed: Feb. 14, 2015.

SANTOS, J.D.G. et al. Chemicals from Agave sisalana Biomass: Isolation and Identification. International Journal of Molecular Science, v.16, n.4, p.8761-8771, 2015. Available from: $<$ http:// www.mdpi.com/1422-0067/16/4/8761/htm>. Accessed: Nov. 27, 2014. doi: 10.3390/ijms16048761.

SHARMA, S.; VARSHNEY, V.K. Chemical analysis of Agave sisalana juice for its possible utilization. Acta Chimica \& Pharmaceutica Indica, v.2, p. 60-66, 2012, Available from: $<$ http://www.tsijournals.com/chemical-sciences/chemicalanalysis-of-agave-sisalana-juice-for-its-possible-utilization.pdf $>$. Accessed: Mar. 14, 2015.

SILVEIRA, R.S. et al. Action of sisal (Agave sisalana, Perrine) extract in the in vitro development of sheep and goat gastrointestinal nematodes. Experimental Parasitology, v.131, p.162-168, 2012. Available from: $<$ http://www.sciencedirect.com/science/article/pii/ S0014489412001129>. Accessed: Feb. 13, 2015. doi: 10.1016/j. exppara.2012.03.018.

UENO, H.; GONÇALVES, P.C. Manual para diagnóstico das helmintoses de ruminantes. Tokyo: Japan International Cooperation Agency, 1998. 147p.

VERCRUYSSE, $J$. et al. International harmonisation of anthelmintic efficacy guidelines. Veterinary Parasitology, v.96, p.171-193, 2001. Available from: <http://www.sciencedirect.com/ science/article/pii/S030440170000443X $>$. Accessed: Feb. 12, 2015. doi: 10.1016/S0304-4017(00)00443-X.

VOLCHEGORSKII, I.A. et al. Comparative analysis of the anxiolytic effects of 3-Hydroxypyridine and succinic acid derivatives. Bulletin of Experimental Biology and Medicine, v.158, p.756-761, 2015. Available from: <http://link.springer.com/ article/10.1007/s10517-015-2855-3>. Accessed: Mar. 10, 2015. doi: $10.1007 / \mathrm{s} 10517-015-2855-3$

WANG, J. et al. Succinate production from different carbon sources under anaerobic conditions by metabolic engineered Escherichia coli strains. Metabolic Engineering, v.13, p.328-335, 2011. Available from: $<$ http://www.sciencedirect.com/science/article/pii/ S1096717611000334>. Accessed: Feb. 10, 2015. doi: 10.1016/j. ymben.2011.03.004. 